\title{
IMPLEMENTASI TEKNOLOGI IoT PADA SMART HOME
}

\author{
Febryan Ramdani ${ }^{1}$, Harry Dhika ${ }^{2}$ \\ ${ }^{1}$ Jaringan Komunikasi , Informatika, Unindra PGRI \\ Email: ${ }^{1}$ Febryanramdani@gmail.com
}

\begin{abstract}
Abstrak. Indonesia hingga saat ini telah menerapkan berbagai teknologi telekomunikasi untuk Meningkatkan kualitas dan meningkatkan kualitas sehingga perbaikan perlu dilakukan di semua bidang, salah satunya adalah Infrastruktur Telekomunikasi. Teknologi Internet of Things (IoT), menawarkan layanan dan jaringan yang cerdas. Tetapi untuk mengimplementasikan teknologi IoT membutuhkan banyak biaya dan cukup mahal, oleh karena itu perlu dirumuskan strategi yang cocok untuk menerapkan teknologi IoT. Untuk merumuskan rencana berdasarkan konsep ilmu manajemen strategis menggunakan formulasi strategi menggunakan proses strategi yang terdiri dari MEI (Evaluation Matrix Internal), MEE (External Evaluation Matrix), SWOT, External Internal Matrix, dan Grand Strategy. Setelah dirumuskan, ditemukan bahwa "strategi $3 R$ dan kemudian secara perlahan menerapkan teknologi IoT" adalah strategi terbaik dan dapat diterapkan.

Kata Kunci: Internet of Things (IoT), Smart Home, SWOT, External Internal Matrix and Grand Strategy (GS)

Abstract. Indonesia to date has implemented a variety of telecommunications technologies for Improving quality and improving quality so that improvements need to be done in all fields, one of them is Telecommunications Infrastructure. Internet of Things (IoT) technology, offering smart services and networks. But to implement IoT technology requires a lot of costs and is quite expensive, therefore it is necessary to formulate a strategy that is suitable for implementing IoT technology. To formulate a plan based on the concept of strategic management science using strategy formulation using a strategy process consisting of MEI (Evaluation Matrix Internal), MEE (External Evaluation Matrix), SWOT, External Internal Matrix, and Grand Strategy. After formulating it was found that the " $3 R$ strategy and then slowly applying the IoT technology" is the best and workable strategy.
\end{abstract}

Keywords: Internet of Things (IoT), Smart Home, SWOT, External Internal Matrix and Grand Strategy (GS)

\section{Pendahuluan \\ 1.1. Latar Belakang}

IoT or often called the Internet of Things is a technology that aims to expand the utilization of an internet connection that is always connected, here are the benefits of IoT: Sharing data and others, including objects in the world that are connected with local and global internet networks through the sensor is embedded and is always "ON". Basically, everything related to the internet or IoT (Internet of Things) refers to objects that are uniquely known as real representations in local and universal Internet-based structures. The IoT, which stands for Internet of Things, was originally suggested by Kevin Ashton in 1999 and began booming through the MIT Auto-ID Center. The government has planned and is ready to implement IoT for future technology needs to make all D2D well connected in making it easier to access all networks with Smart, but in implementing it requires a strategy of how this technology can assist in administration in Government.

\subsection{Perumusan Masalah}

Based on the background, the problem can be formulated as follows:

1. How to analyze SWOT in implementing IoT Technology on the network for Smart Home?

2. How to make and design suitable strategies to implement the application of IoT (Internet of Things)Technology on the Smart Home Network?

\subsection{Metode dan Tujuan Penelitian}


The methods include the formulation of the Strategy, the Input Phase, and the data matching stage and the Strategy decision, which uses SWOT analysis, IE (Internal and External) and GS (Grand Strategy).

The purpose of this research is to analyze the problem of the application of IoT (Internet of Things) on the internet network and create a plan for its application, then determine the appropriate plan for the Application of IoT (Internet of Things) on the Smart Home network.

\section{Kajian Pustaka}

\subsection{Kajian Pustaka}

Previous studies relating to this research include the following:

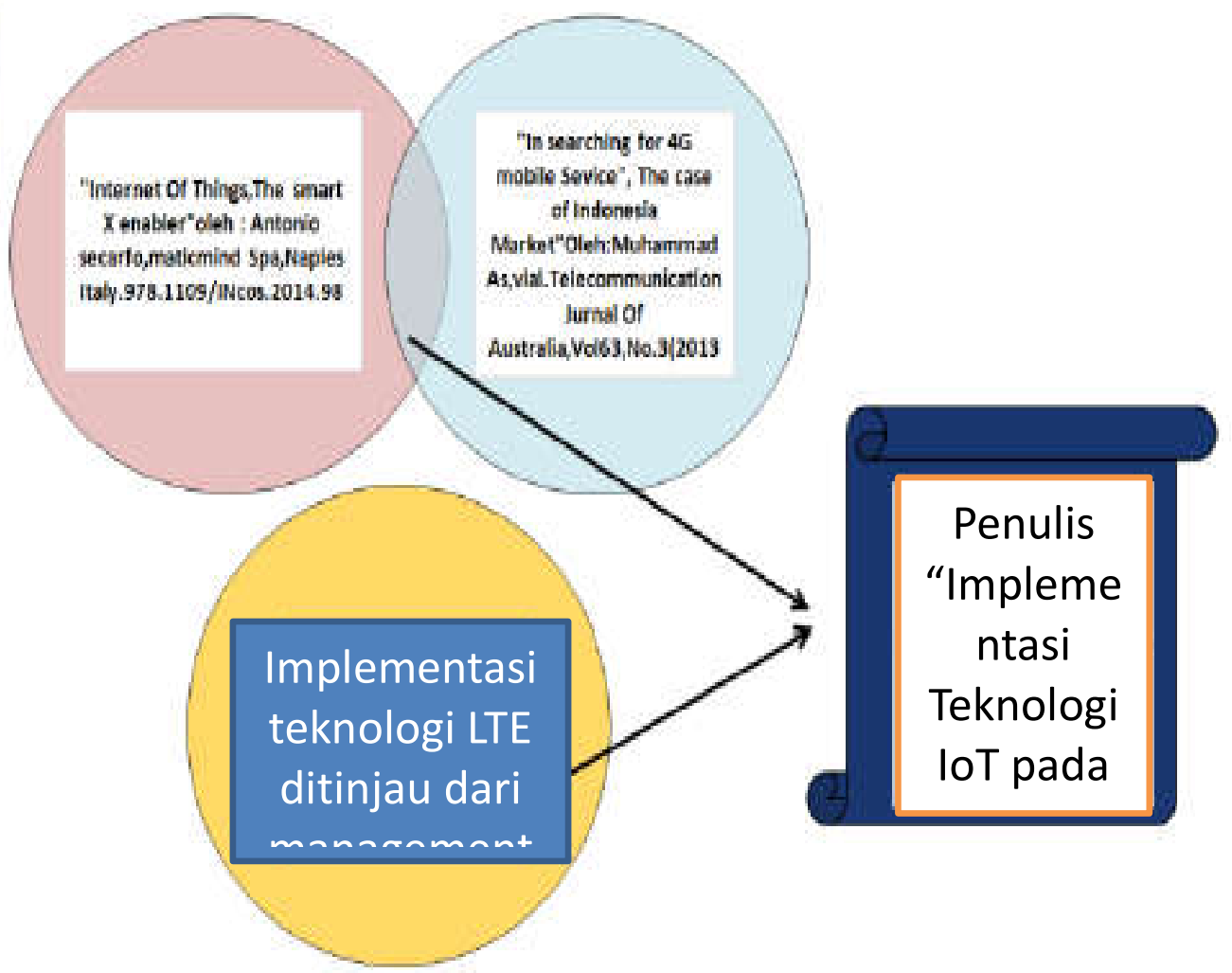

(1) IoT (Internet of Things, The Smart X Enabler: International Conference on Intelligent Nerworking and Collaborative Systems 2014 presented by Antono Secarfo, Maticmind Spa, Napies Italy

This research is about Project Implementation of IoT that can add value. The ICT management process will be very useful in providing solutions to modern telecommunications practices.

On the other hand, what must be dealt with is the application that is not easy because the infrastructure of the internet network and regulations greatly affect the results of the use of IoT, in this study that IoT is very helpful for improving Telecommunications Infrastructure.

(2) In Searaching for $4 \mathrm{G}$ mobile service Applications, the case of Indonesian Market, Muhamad suryanegara, Muhamad Asvial, Telecommunications Journal of Australia, vol 63 No.3 (2013)

This journal discusses the increasingly strong role of cellular telecommunications technology, thereby driving demand for new features from $4 \mathrm{G}$ applications. By focusing on examples of technology in Indonesia, 
an analysis of $4 \mathrm{G}$ characteristics of mobile service applications will be conducted in the future which may be popular in developing countries. To make an analysis, surpey was carried out on several people who were representatives of $4 \mathrm{G}$ service technology and its application within 5 years. The journal also developed a model to identify challenges and opportunities for national players in the mobile communications sector, namely operators and content developers.

The results show that the initial source of innovation services is the possibility of originating from the pooling of knowledge from the local perspective of a country together with the global trends in mobile service applications. The combination of these two things will create a new service that allows to be very quickly appointed by the government.

(1) Implementation of LTE Technology Reviewed from the Implementation Strategy management This research has the aim to Analyze the Implementation Strategy of LTE Technology in. Indonesia to date has implemented a variety of telecommunications technologies. To meet customer and quality improvement, improvement is needed in all blocks. One of them is telecommunications infrastructure. LTE technology or Long Term Evolution is one of the 4G-based technologies following the change from $3 \mathrm{G}$ that has been implemented in Indonesia. Is one of the operators that have conducted trials for LTE technology. But like when implementing $3 \mathrm{G}$ after $2 \mathrm{G}$, besides the quite expensive cost, many things need to be considered in implementing LTE. Therefore, it is necessary to formulate a suitable plan for implementing LTE on the Internet network in Indonesia. Research in this thesis is carried out by formulating a plan, in terms of implementing LTE networks. Strategy formulation is based on the concept of strategic management science using the strategy formulation method consisting of Internal Evaluation Matrix (MEI), External Evaluation Matrix (MEE), SWOT, External Internal Matrix (MIE), Grand Strategy Matrix (MGS), and QSPM. After formulation, it was found that the plan "Continuing DATA and VAS services at this time by increasing the number of customers through the Customer Lifecycle Management and ICE system and then implementing LTE slowly" is the best strategy and can be implemented.

\subsection{Internet Of Things(IOT)}

The Internet Telecommunication Union (ITU) details IoT as "A global infrastructure for the Information Society, enabling sophisticated services by interconnection on (physical and virtual) based, existing and developing technologies, interoperable information and communication technologies.

Internet of Things (IoT) is a technology that integrates various things with the internet using a variety of sensors whose results are processed into a specific output. The sensors that are commonly used include: RFID, Infrared, GPS, and laser scanners. This IoT is generally applied in the world of transportation, environment, security and also smart home.

IoT affects human life, where at this time humans can not be separated from the internet. By utilizing these IoT in general can improve the quality of human life better. Development of smart home will help facilitate human life where by integrating various sensors in a network can do various things such as tracking, recognition, surveillance and other things.

\subsubsection{Materi dalam Internet Of Things ( IoT)}




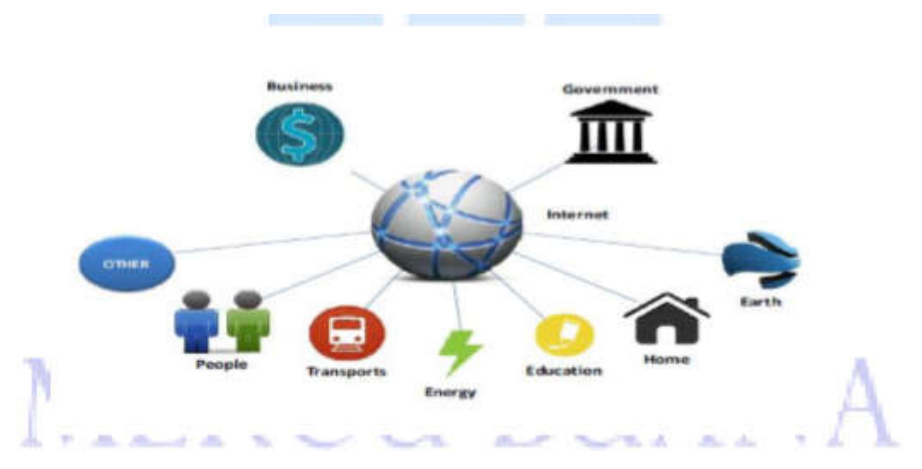

Internet of Things (IoT) is a material that aims to multiply the benefits of an endless internet connection. As for those who have capabilities such as sharing data, remote control, and so on, including objects connected to the internet, with electronic examples, collections, any equipment, including living objects that are all connected to local and universal networks through embedded

sensors

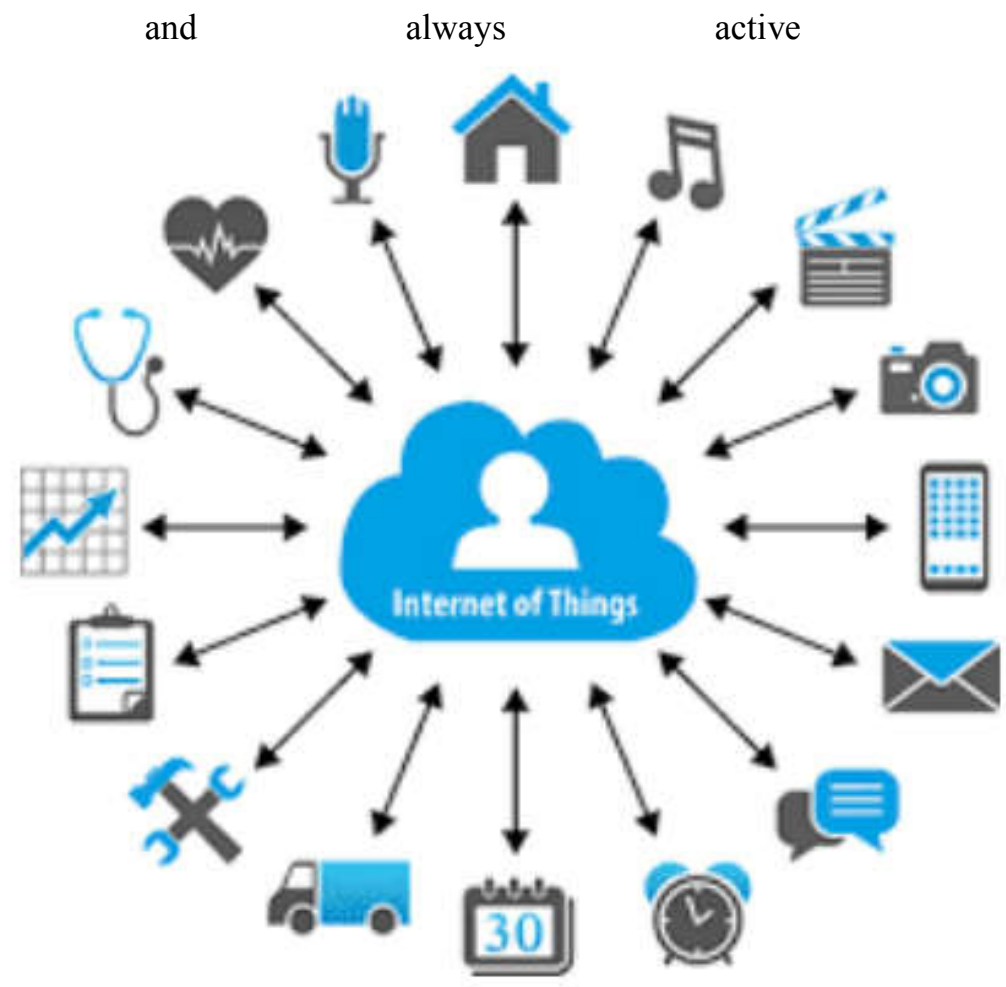

Basically, IoT (Internet of Things) is guided by objects that can be uniquely identified as virtual representations included in Internet-based structures. IoT or often referred to as the Internet of Things was first suggested by Kevin Ashton in 1999 and was first famous through Auto-ID at MIT, and now IoT has become one of the assignments of a student at a University throughout Indonesia.

\subsubsection{Seluruh Lapisan IoT}

\section{Pada lapisan IoT terdiri dari beberapa lapisan sebagai berikut :}




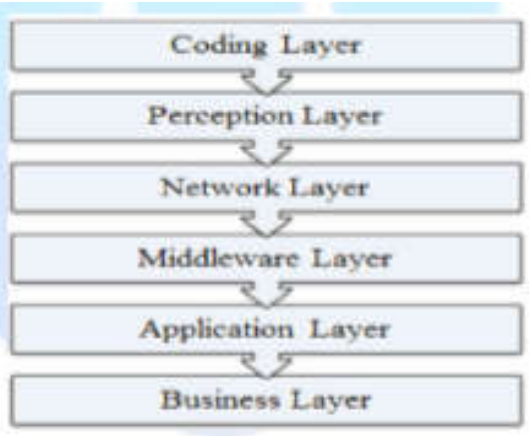

\section{Coding layer}

Coding layer on the basis of IoT that provides identification with interesting objects. And in this layer each object is given a unique ID and makes it easy to distinguish objects.

\section{Layer Perception}

This is a device layer of IoT that gives a physical meaning to each object, It consists of sensor data in different forms such as RFID tags, IR sensors or other sensor networks that can sense temperature, humidity, speed and location etc. of the object. This layer can collect useful information from objects from sensor devices connected to them and change digital signal information which is then forwarded to the Network Layer for further action.

\section{Network Layer}

The purpose of this layer is to receive useful information in the form of digital signals from the Layer Perception and send it to the processing system in Middleware. Layer through the forwarding of media such as WiFi, Bluetooth, Zigbee, GSM, 3G, 4G etc. with the protocols Ipv6, Ipv4, DDS etc.

\section{Application Layer}

This layer is aware of the application of IoT (Internet of Things) for all types of industries, based on the data created. Because the application promotes the development of large-scale IoT (Internet of Things) networks so that this layer is very helpful in the development of large-scale IoT networks. related can be a Smart Home, Smart Transportation etc.

\section{Business Layer}

This layer manages the applications and services of IoT and has responsibility for all research related to IoT, producing different types of models for effective business strategies.

\subsubsection{Penerapan Teknologi IoT(Internet of Things)}

IoT can be applied in various fields of telecommunications. Some fields that have used IoT technology as follows:

1. Smart City

Useful for managing cities such as paying attention to parking locations, buildings or buildings, and monitoring noise in real-time and so on.

2. Smart Environment.

Generally used to monitor and track forest fires, snow levels and other natural disasters.

3. Smart Metering and Home Automation.

Usually this technology is used to monitor and regulate energy, water tanks and so on.

4. Security \& Emergency.

This technology is used to detect people in prohibited areas and such as natural disaster radiation, and also harmful gases.

5. Logistic.

Monitor the location of goods being shipped and goods in warehouses and fleet tracking for goods such as drugs and other chemicals etc. 
6.Industrial Control.

To monitor every sensor in an industry such as hazardous gas at the factory, regulate the temperature and level of ozone in the drying of meat at the Logistics company and can collect information from CanBuss to help the driver.

7. Smart Agriculture and Animal Farming.

In general, is to monitor the state of the soil in agriculture, sensors in the green house, monitor the state of animals and monitor the temperature and humidity levels.

8.Health

It is generally used to detect a person's health such as monitoring the condition of the patient (heart rate, blood pressure, and breathing), measuring UV light, monitoring the body while exercising, and detecting it for an elderly person. The development of technology will reach its peak when it has touched on IoT technology where all can be connected both physically and virtually in a network that goes to one point. IoT is the future technology that connects all electronic devices with IPbasedtelecommunications where, devices can monitor, analyze and be controlled remotely by utilizing local and universal internet networks.

\subsection{Application of IoT to the Indonesian Internet network}

At this time the Government has conducted a trial using 3 internet services of things

\section{Yubox}

Yubox is one of the WiFi connections to provide access to the internet, music and video applications to users who access it. Users can enjoy the entertainment in the form of streaming streams or can be directly downloaded into their mobile phones. It is currently a solution that is being trialled at one of the partners running on public transportation.

\section{Savvy Smartphone}

Savvy Smartphone is an application that is connected to cloud computing and can be used to control a number of household appliances wirelessly. For example, to regulate the temperature of air conditioners in the house, turn on or turn off lights, access surveillance cameras and replace television channels. All can be done remotely as long as there is an internet connection.

\section{Xmart City}

Xmart City is an IoT implementation program in accordance with the city's increasingly high needs. This program has been running in Lombok, Banjarmasin, Balikpapan and Yogyakarta. The new solution is offered to corporate segment users. However, the Government did not rule out the possibility to offer various IoT solutions to individual users or consumers.

\subsubsection{Implementasi Smart Home}

The term smart home may already be familiar at this time. Many overseas vendors of Internet of Things (IoT) are also aggressively developing smart homes. In addition to making it easier for residents to manage their homes, the concept of smart homes also provides security for residents.

Then what about the concept of smart home in Indonesia? Is this concept suitable to be implemented in Indonesia? With the need for up to 13.5 million residential units in 2015 (quoted from antaranews), this makes Indonesia the right location for Smart Home Implementation. Not only for housing, apartments also began to be looked at in Indonesia.

The need for safety and comfort in residential homes is increasing in Indonesia. The Smart Home concept itself has been introduced in Indonesia. Many domestic vendors are starting to develop the technology. This concept is increasingly becoming an idol with a touch of IoT in it. With IoT, residents of the house easily manage their home only through a smartphone. 
The toughest challenge of implementing smart home in Indonesia is convincing the public. Quoted from Okezone, smartphone users in Indonesia reached 55 million. Seeing this fantastic number, some people will think it is easy to implement smart homes in Indonesia because the tools that are the main controller already have 55 million people in Indonesia.

\subsubsection{Overview of Smart Home}

Smart home technology is increasingly popular, because it provides convenience and security for the home and its inhabitants. Simply holding a smart phone, users can control all electronic devices in the house. Not only for users, property developers also consider smart home technology as an added value that can be offered to hook potential customers. The presence of smart home devices is not just a trend, but has become a necessity for

today's modern society. "Applying the concept of a smart home will be a plus for developers. As a pioneer who puts forward the concept of smart development, the application of this concept will certainly make developers innovative, the use of smart home devices will certainly provide benefits, for developers as well as consumers.

\subsection{Strategy management strategies}

The concept of strategy management is all that includes understanding and methods in the analysis involving strategies and management that are in accordance with applicable standards and are commonly used in studies on the theme of strategy management

\subsubsection{Definisi Manajemen Strategi \\ A. Manajemen}

Understanding of management according to some experts varies greatly, including: according to Nickles, Mc Hingh and Mc Hugh (1997), "management is the process used to accompany organizational goals through planning, organizing, directing, and controlling people and other organizational resources". Management is a process carried out to realize organizational goals through a series of activities in the form of planning, organizing, directing and controlling people and other organizational resources. Ricky W. Griffin defines management as a process of planning, organizing, coordinating and controlling resources to achieve goals (goals) effectively and efficiently. According to George R. Terry, "management is a process of activities consisting of planning (organizing), organizing (organizing), actuating (implementing) and controlling (controlling) performance by using human resources to achieve predetermined goals."

\section{B. Strategy}

According to David (2009, p18), strategy is a joint means with long-term goals to be achieved. The business strategy includes geographical expansion, diversification, acquisition, product development, market penetration, tightening, divestment, liquidation, and joint ventures. According to Pearce and Robinson (2008, p6), strategy (strategy) is a large-scale plan, with a future orientation, in order to interact with competitive conditions to achieve company goals. The strategy reflects the company's knowledge of how, when and where the company will compete; whom the company should compete with; and for what purpose the company is competing. According to Stephanie K. Marrus in Umar (2005, p31), strategy is a process of determining the plans of top leaders who focus on the long-term goals of the organization, along with the preparation of a way or effort on how to achieve these goals. According to Rangkuti (2009, pp3-4), strategy is a tool to achieve goals. This can be demonstrated by differences in strategy over the past 30 years.

\section{Strategy Management}

Strategic management can be defined in various ways. According to Wheelen's and Hungry Studies $(2006,3)$, strategic management is a set of managerial decisions and actions that determine the longterm performance of a company. This involves a scanning environment (both external and internal), 
strategy formulation (strategic or long-term planning), implementation of the strategy, and evaluation and control. They emphasize analyzing and evaluating external opportunities and threats in terms of organizational strengths and weaknesses. (Wheelen \& Hunger 2006, 3).

According to David (2009, p5) strategy management is the art and knowledge of formulating, implementing, and evaluating cross-functional decisions that enable an organization to achieve its goals. As this definition implies, strategic management focuses on efforts to integrate management, marketing, finance / accounting, production / operations, research and development, and computer information systems to achieve organizational success.

The hierarchy of strategies that exist in an organization is grouped into 3 levels, namely corporate strategy, business unit strategy and functional / operational strategy.

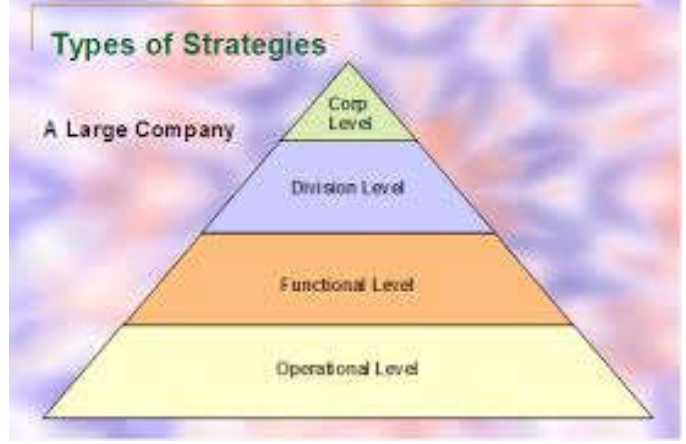

\subsubsection{Tahapan Penyusunan Strategi}

Strategy management is a process that is bound or consists of a series of stages that will try to be simplified as in the following chart:

The Strategic Management Process Dalam "The Strategic Management Process" ada beberapa tahapan penting yang harus dilalui yaitu:

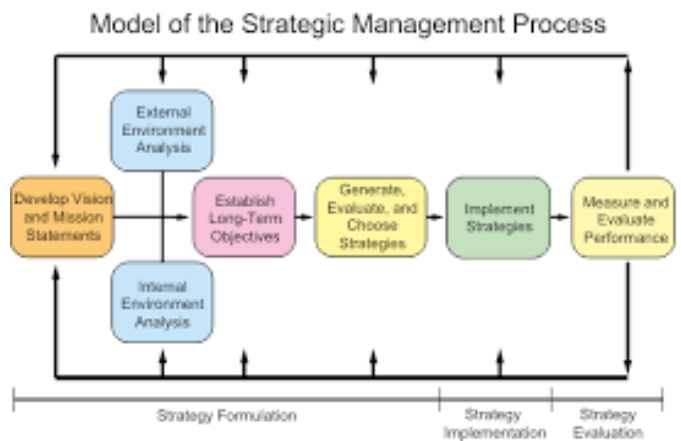

1. Identify the Mission, Objectives and Strategies of the Company

Basically every company needs a mission statement that is useful for achieving the goals of the company. The mission is to answer all questions at the beginning of the formation of the business. With the clear mission of an organization, the company can identify with the scope of its products and services.

2. External Analysis

In the second stage, the management analyzes the situation which is an important step in the process of forming the right strategy. This stage is useful to meet the company's curiosity about several things such as how the competition is there, regulations that can affect the company, how about the supply of resources related to the company's location. In analyzing the external situation, the company must be able to analyze the good conditions specifically

and overall to see trends and changes that might occur. After conducting an environmental analysis, the company needs to study opportunities that could be exploited and threats that must be avoided by the company. However, in conducting external analysis, it is important to know that in a situation, 
opportunities that can be utilized by a company and at the same time become a threat to other companies engaged in the same industry related to the resources and capabilities they have.

3. Internal Analysis

Internal analysis must lead to a clear interpretation of the resources owned. Every activity carried out by the organization well and all types of unique resources possessed by the company's management can be said to be strengths (strength) while all company activities that are carried out improperly or limited resources owned can be a factor of weakness (weekness). At this stage, companies must be able to understand the specifications of each resource and its capabilities.

4. Strategy Formulation

After the SWOT analysis is done, managers must be able to develop and evaluate alternative strategies that can maximize the strength of the company and explore opportunities so that they can improve their deficiencies and avoid potential threats.

5. Strategy Implementation

After the strategy is formulated, the strategy must be immediately implemented as well as possible so as to produce maximum results and benefit the company's progress.

6. Evaluation of Results

The last stage is the stage where the evaluation process is carried out on the results of the strategies that have been implemented. This is useful to find out whether the strategies carried out are effective or still need some adjustments that can maximize the results of these strategies.

2.4.3 Kerangka Perumusan Strategi

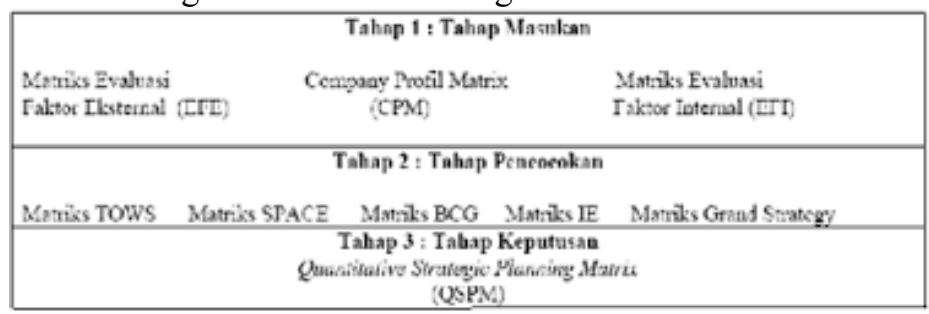

\section{A. Tahap Input}

According to David (2009, p325) procedures for developing the EFE Matrix, IFE Matrix, and CPM. The information obtained from these three matrices becomes the basic input information for the matrices of the matching and decision stages. Input tools encourage the strategists to measure subjectivity during the initial stages of the strategy formulation process. Making small decisions in the input matrix concerns the relative significance of external and internal factors, enabling strategy makers to more effectively create and evaluate alternative strategies. Good intuitive judgment is always needed in determining the right weight and ranking.

\section{B. Matching Stage}

According to David (2009, pp325-326) strategy is often defined as the match made by an organization between its internal resources and skills and the opportunities and risks created by external factors. The matching phase of the (adjusted) strategy formulation framework consists of two techniques that can be used in any order: the SWOT Matrix, and the IE Matrix. These tools depend on information obtained from the input stage to combine external opportunities and threats with internal strengths and weaknesses. Matching important external and internal success factors is the key to creating alternative strategies that make sense.

\section{Decision Stage}

Analysis and intuition become the basis for making strategic formulation decisions. The matching techniques used describe various alternative strategies that can be taken. Many of these strategies are likely to be proposed by managers and employees who participate in the analysis and strategy selection activities. Any additional strategies that result from matching analyzes can be discussed and added to reasonable alternative choices. 


\subsection{Metode Analisa}

Analysis method is used to be an analysis tool when mapping cases on the theme of strategy management or others.

\subsubsection{Strength- Weakness- Opportunity- Threath (SWOT)}

According to David (2004, p31) SWOT analysis is a tool used to compile company strategic factors, or systematic analysis to identify external and internal factors, opportunities and threats faced by a company. This analysis is based on logic that can maximize strengths and opportunities (oppurtunities), but simultaneously can minimize weaknesses (threats) and threats (Threat) :

\section{Faktor Internal}

$>$ Strength (strength) Resources, expertise or other advantages relative to competitors and the needs of the market (consumers) where the company operates or hopes to operate.

$>$ Weakness (weakness) Limitations or deficiencies in resources, expertise and abilities that interfere with the effectiveness of the company's performance.

\section{Faktor Eksternal}

$>$ Opportunity (opportunity) The main favorable situation in the corporate environment. Key trends and change are one source of opportunity.

$>$ Threats (challenges) The main disadvantageous situation in the corporate environment. The strategic decision making process is always related to the development of the company's mission, goals, strategies and policies. Thus the strategic planner (strategic planner) must analyze the company's strategic factors (strengths, weaknesses, opportunities and threats) in the current conditions.

\begin{tabular}{l|l|l|}
\hline \multicolumn{1}{|c|}{ IFAS } & Kekuatan (Strength) & Kelemahan (Weakness) \\
\hline PFAS & $\begin{array}{l}\text { STRATEGI SO } \\
\text { Ciptakan strategi yang } \\
\text { menggunakan kekuatan } \\
\text { untuk memanfaatkan } \\
\text { peluang }\end{array}$ & $\begin{array}{l}\text { STRATEGI WO } \\
\text { Ciptakan strategi yang } \\
\text { meminimalkan kelemahan } \\
\text { untuk memanfatkan } \\
\text { peluang }\end{array}$ \\
\hline Ancaman (Threats) & $\begin{array}{l}\text { STRATEGI ST } \\
\text { Ciptakan strategi yang } \\
\text { menggunakan kekuatan } \\
\text { untuk mengatasi ancaman }\end{array}$ & $\begin{array}{l}\text { STRATEGI WT } \\
\text { Ciptakan strategi yang } \\
\text { meminimalkan kelemahan } \\
\text { dan menghindari ancaman }\end{array}$ \\
\hline
\end{tabular}

The following is a description of each strategy:

1. SO Strategies utilize the company's internal strengths to take advantage of external opportunities. All managers naturally want their organization to be in a position where internal power can be used to take advantage of external trends and policies. In general, organizations will carry out WO, ST, or WT strategies to achieve situations where they can implement SO Strategies.

2. The WO Strategy (WO Strategies) aims to correct internal weaknesses by taking advantage of external opportunities. Sometimes big opportunities arise, but the company has internal weaknesses that prevent it from taking advantage of those opportunities.

3. ST Strategies (ST Strategies) use the strength of a company to avoid or reduce the impact of external threats. This does not mean that a strong organization must always face threats directly in the external environment.

4. WT Strategies (WT Strategies) are defensive techniques aimed at reducing internal weaknesses and avoiding external threats. An organization that faces various external threats and internal weaknesses 
is truly in a dangerous position. In reality, such companies may have to struggle to survive, commit margins, shrink, declare bankruptcy, or choose liquidation.

2.5.2 External Factor Strategy (EFE) and Internal Factor Strategy (IFE)

In an effort to produce competitive company strategies, in addition to analyzing company strategies, it is necessary to first review the environmental situation faced by the company today. The corporate environment consists of two types: external environment (external environment) and internal environment (internal environment). From each of these environments, factors that influence company performance are generated. Factors originating from the external environment called the External Factor Strategy (EFE), are compiled to formulate a framework of Opportunities and Threats. Meanwhile, the factors derived from the internal environment called the Internal Factor Strategy (IFE) are arranged to formulate internal strategic factors within the framework of strengths and weaknesses.

\subsubsection{Grand Strategy}

After going through the analysis process with various parameters and company positioning has been clearly known, the next process is the determination of the Grand Strategy. Still according to David (2009, pp347-349) the Grand Strategy Matrix (Grand Strategy Matrix) has become a popular tool for formulating alternative strategies using two evaluative dimensions:

competitive position and market growth (industry). The right strategy for organizational consideration is shown in the order of attraction in each matrix quadrant.

DIAGRAM 3.7. PENENTUAN MATRIKS GRAND STRATEGY

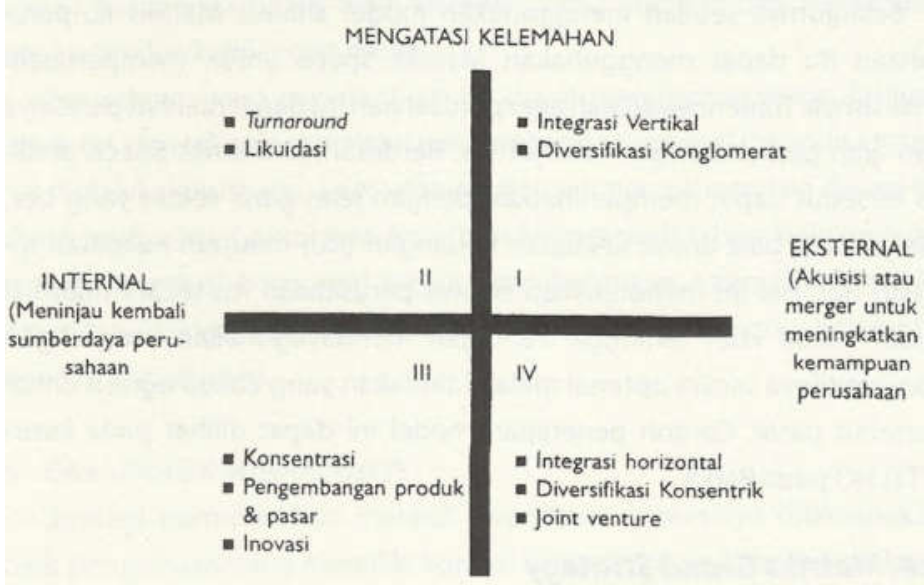

\section{METODOLOGI PENELITIAN}

\subsection{Perumusan Strategi}

Strategy formulation is the formulation of strategies for the steps of analysis and methods in management research studies, for example, as in the theme of implementation strategies.

3.1. 1 Formulation Formulation Method

a strategy is needed if a growing market has begun to be incompatible with the company's long-term goals. The market is changing due to changes in buyer needs, new technology, socioeconomic forces, and competitive activities. These changes create new opportunities and threats for companies to serve the market. The research method is based on the theory of market situation analysis. According to Cravens (2000), Analyzing competitive market situations is the first step in designing new strategies or reviewing existing strategies. This situation analysis is carried out after the strategy is implied to determine the necessary strategic changes. Situation assessment is usually the definition and analysis of the market, and competitor analysis. As a company that is developing and experiencing intense competition in the telecommunications world, formulating a suitable strategy if done with the concept of strategic management. Before formulating a strategy, there are several steps that are carried out in order to achieve the desired goals. The stages are in accordance with the picture. 
Analytical Framework for Research Strategic Formulation

\begin{tabular}{|c|c|}
\hline \multicolumn{2}{|c|}{ Tahap 1: Tahap Pengumpulan Data } \\
\hline Matriks Evaluasi Faktor External (EFE) & Matriks Evaluasi Faktor Internal (IFE) \\
\hline \multicolumn{2}{|c|}{ Tahap 2: Tahap Pencocolcan } \\
\hline $\begin{array}{c}\text { Matriks Kelemahan-Keluatan-Peluang- } \\
\text { Ancaanan (SWOT) }\end{array}$ & Matriks Internal External(IE) \\
\hline \multicolumn{2}{|c|}{ Tahap 3: Tahap keputusan } \\
\hline \multicolumn{2}{|c|}{ Matrix Strategi Besar(Grand Startegy) } \\
\hline
\end{tabular}

\subsection{Method of collecting data}

\subsubsection{Literature Study}

Literature study is carried out by collecting information relating to theories related to this research. Theoretical concepts from various sources such as research journals, literary books, articles in magazines, research work in the form of post graduate studies are studied to obtain a theoretical foundation that can be used to develop research concepts, the literature is emphasized on the concept of business strategy, analysis SWOT, Grand Matrix Analysis and competitive profile of government. 